Journal of Economics and Behavioral Studies

Vol. 6, No. 8, pp. 682-689, August 2014 (ISSN: 2220-6140)

\title{
Attributes of Shopping Mall Image, Customer Satisfaction and Mall Patronage for Selected Shopping Malls in Southern Gauteng, South Africa
}

\author{
${ }^{1}$ Dorah Dubihlela, * Job Dubihlela ${ }^{2}$ \\ ${ }^{1}$ Vaal University of Technology, Vanderbijlpark \\ ${ }^{2}$ NMMU, North Campus Summerstrand, Port Elizabeth, South Africa \\ *dubindlela@gmail.com
}

\begin{abstract}
This paper identifies the main features of a shopping mall that govern customer satisfaction in Southern Gauteng in South Africa. Literature is reviewed, identifying various features in shopping malls such as merchandisers, accessibility, service, amenities, ambiance, entertainment, security and among others. This literature is based on previous authors' scientific work, on mall features that influence the satisfaction and patronage by customers. A quantitative study was conducted with 429 questionnaires used in the final data analysis. The study results suggest the important shopping mall features in Gauteng South in South African and confirm that specific shopping mall features are positively related to customer satisfaction and mall patronage. The paper further develops suggestions on mall features that should be emphasised for promotional campaigns, customer satisfaction and mall patronage by customers.
\end{abstract}

Keywords: Shopping mall, mall features, customer satisfaction, mall-patronage, South African

\section{Introduction and Background of Study}

Shopping malls are becoming dynamic, deviating from the conventional shopping centres to creative structures that satisfy modern consumers. The term mall image emerged from Martineau (1958), as the way in which the mall is perceived in the minds of the shoppers who patronise it. Customer satisfaction in a mall is largely determined by the mall image and its attributes (Anderson \& Sullivan, 1993). The mall attributes bring complete impression in the customer's memory due to the features associated with both the current and previous exposures (Hartman \& Spiro, 2005). Grewal, Baker, Levy and Voss (2003) suggested that mall image attributes are predictors of shopping mall choice while Kim and Jin (2001) perceive mall image attribute as a possible significant factor in drawing customers to a shopping place. Despite the fact that consumers usually seek to minimise travel time, mall image attributes have the ability to reduce the undesirable issues caused by travel distance (Stanley \& Sewall, 1976). Malls with a favourable atmosphere increase the positive purchasing practice, customer satisfaction and affects the time and amount of money customers spend per visit (Babin \& Darden, 1996). Satisfactory atmosphere, together with mall convenience represent an important aspect of mall environmental stimuli (Hilderbrandt, 1988). Regarding the connection between image attributes and customer fulfilment, Bigne, Sanchez and Sanchez (2001) suggest that image perceptions affect satisfaction through influence on customer's expectations before mall visits. Customer satisfaction rests on the comparison between expectations and real service. Scholars have conceptualised mall image attributes like assortment, facilities, market posture, merchandising, mall atmosphere, in-mall service, reputation, accessibility, promotions and after-transaction service (Thang \& Tan, 2003). Furthermore, past research has revealed that mall image perceptions are influenced by merchandise assortments (Anselmsson, 2006) and perceptions regarding the performance of salespeople and quality (Darian, Tucci \& Wiman, 2001). Features which compromise mall image have been developed and challenged by (Zimmer \& Golden, 1988).

\section{Literature Review}

Mall image is a multi-dimensional component (Bloemer \&De Rutyer, 1998) consisting of both the visible features such as the superiority and availability of goods and services (Chang \& Tu, 2005) and the less tangible features like the atmosphere of the mall (Koo, 2003). The definition of mall image has evolved from the time it was presented by Martineau (1958). Wyckham (1967) defined mall image as the consumer's total 
perception of mall attributes, formed as a result of the shopping practice. Doyle and Fenwick (1975) describe mall image as the consumer's evaluation of all noticeable features of the mall. Hartman and Spiro (2005) further posit that the origin of mall image is an overall memory resulting from mall attribute perceptions based on acquaintance to the mall. Nevin and Houston (1980) analysed image attributes of shopping malls and noted three main brand qualities of shopping malls which are assortment (quality of goods, diversity of stores, range of goods, sales promotion, special events); facilities (layout of a shopping mall, parking lot, relaxed recreational areas) and market position (overall price level, staff and the shopping mall). Mas-Ruiz (1999) cited in Gudonaviciene1 and Alijosiene (2013) distinguished three image attributes of shopping malls which are shopping atmosphere, parking and professionalism. Past research on mall patronage utilised independent measures such as distance to the shopping mall, population size and mall-space (Brunner \& Mason, 1968; Bucklin, 1967). It is at the back of this that Huff (1964) developed a model for predicting mallpatronage which was based on the opinion of the cost of shopping verses its utility. Latter, the rationality of the model was questioned particularly because of its assumptions of analogous mall patronage decisions by shoppers of different educational levels, incomes and occupational classification. Following this, the next research interest on mall patronage gave an increasing emphasis on customers and other prompting factors in mall patronage like image attributes and motives (Nevin \& Houston, 1980), image (Hunter, 2006) and situational variables (Zhuang-Zhuang, Tsang, Li \& Nicholls, 2006).

There are numerous motives and intentions for shopping mall patronage. Loudon and Britta (1993) noted that better interior design promotes the mall image over a period of time. A research by Woodside and Trappey (1992) pointed out that customers could quickly name a mall when asked what mall comes to mind for precise features such as favourable prices and convenience. The interaction of these tangible and intangible fundamentals widely determine mall image (Hirschman, 1981). According to Oxenfeld (1974) mall image is a concept which is more than the summation of its fragments; including extraneous elements, emotional content and with factual material. The attractiveness of a mall and its attributes are inseparable. Often, customers make decisions about the choice of a shopping mall grounded on its image attributes and image (Anderson \& Sullivan, 1993). In branding theories, the term brand image often creates an exceptional character of numerous products in the consumer's mind. Likewise, Dennis, Marsland and Cockett (2002) demonstrated that the methods of brand image may be effectively applied for shopping malls to assist increasing customer satisfaction and the marketability of shopping malls. The greater the positive image attributes of a shopping mall, the higher the likelihood of customers visiting it to shop (Arons, 1961). Customers visit a place for shopping whose image is closest to the imaginary one. In customer satisfaction literature, mall image in common (Bloemer \& De Ruyter, 1998), and mall image features in particular (Bloemer \& Odekerken, 2002) are key determinants of customer patronage. The more favourable the mall image, the more likely that customers will be content and frequent it (Crawley, 1993). Commonly, customer satisfaction is an essential condition for achieving satisfaction with the mall. However, Mitchell and Kiral (1998), in reviewing several mall image studies, failed to identify a link between the mall features and customer satisfaction. Likewise, Sivadas and Baker-Prewitt (2000) found that the consumer attitudes driving self-image and mall-image are related to mall satisfaction, nonetheless with no direct effect on mall patronage.

A study on mall features and image is not new. Previous studies have focused on the image attributes of shopping malls that determine mall selection (Finn\& Louviere, 1996, Wong, Lu, Yuan, 2001; Hunter, 2006). The other wave of research has focused on the factors affecting the selection of shopping malls (Arslan, Sezer \& Isigicok, 2010; Singh \& Sahay, 2012) while a study by (Heijden \& Verhagen, 2004) noted that the mall image is determined by managers. Customer satisfaction and mall image attributes are important features for shopping mall developers due to their effect on mall patronage. In the South African context, research on the relationship between mall satisfaction and mall patronage has remained narrow both in actual number and scope. There also exists a lacuna in research about the inter-relationships of these components when they are considered together. A deeper knowledge on how customers react to mall image would be invaluable to both retail marketing researchers and retail managers. Therefore, the fundamental motivation for this research is to create a body of knowledge upon which further studies on mall image attributes and its affiliation to customer satisfaction and patronage can be based. 


\section{Methodology}

A survey method using a fully structured questionnaire was used to obtain the relevant data needed for this study. Malhotra (2004) defines a survey as an interview with large a number of respondents using a predesigned questionnaire. Face-to-face interviews were conducted and placed the respondents at ease, helping to reduce anxiety, increasing the response rate and decreasing potential measurement errors (Tustin, Ligthelm, Martins \& Van Wyk, 2005). In the questionnaire, most references were adapted from the methodology of Sit, Merrileesr and Birch (2003) and Singh and Sahay (2012) to measure attractiveness of shopping malls. Peculiarities of the South African retail sector and the structures of various shopping malls were taken into considerations, together with the high influence of retail networks in South Africa. The questionnaire included a question to establish whether customers considered the importance of the anchortenant in the selection of shopping malls. Five-score Likert-type scale was used to form the questions in all the sections other than the biographic section which contained criteria such as age, gender, education and the transportation means to the shopping mall (customers were divided into those who travel by car and by public transport). Data from 429 usable questionnaires was analysed using descriptive statistics, means, frequency analysis and cross-analysis, as well as exploratory factor analysis.

Reliability: The Cronbach alpha coefficient technique was used to test for the reliability of the survey data. Both Creswell (2003) and Malhotra (2010) state that the Cronbach alpha coefficient values range from 0 to 1. For the assessment of reliability using the Cronbach alpha coefficient, values below 0.60 indicate unsatisfactory reliability, while values ranging from 0.60 and greater indicate moderate to high reliability. The higher the correlation coefficient, the greater the reliability of the measuring instrument.

Validity: Validity assesses whether the instrument used was indeed measuring what it was supposed to measure (Martins, Loubser \& Van Wyk, 1996). A valid instrument must cover the extent to which it provides adequate coverage of the variables being measured. The construct, convergent and discriminant validity tests were used to examine the data.

\section{Results and Discussion}

The data analysis in terms of methodology and formulation of results followed three steps. Frequencies were used to carry out the preliminary analysis of the data, identifying the characteristics of the sample and breaking down questionnaire responses into meaningful data. The factor structure of measurement items was confirmed through exploratory factor analysis (EFA) to establish the dimensions and then the analysis of variances (ANOVA) was used to examine the differences within the sample. The (EFA) directed to the detection of five factors which constitute the important shopping mall attributes in the South African retail market. The relationship between shopping mall attributes, customer satisfaction and shopping mall patronage for the whole sample was then examined.

The following sample characteristics were found from the survey

Table I: Sample characteristics of respondents $(\mathrm{N}=429)$

\begin{tabular}{llll}
\hline Variables & Values & Frequency & Valid (\%) \\
\hline Gender & Male & 233 & 54.3 \\
Family cycle & Female & 196 & 45.7 \\
& Single & 193 & 44.9 \\
& Married & 73 & 17.0 \\
Age & Married with children & 163 & 38.1 \\
& & & \\
& $18-25$ & 102 & 23.8 \\
& $26-35$ & 120 & 28.0 \\
\multirow{2}{*}{ Education level } & $36-45$ & 107 & 24.9 \\
& $46-55$ & 61 & 14.2 \\
& $56+$ & 39 & 9.1 \\
& Below metric & 66 & 15.4 \\
\hline
\end{tabular}




\begin{tabular}{llll}
\hline \multirow{2}{*}{ Shopping frequency } & Tertiary level & 122 & 28.4 \\
& $\begin{array}{l}\text { Very often (two times/week) } \\
\text { Often (once every week or less) } \\
\text { Less often (once every 15 days- } \\
\text { month) } \\
\text { Seldom(less than one time/month) }\end{array}$ & 131 & 30.5 \\
& 20 & 7.2 \\
\hline
\end{tabular}

The primary stage of the analysis for this study involved an exploratory factor analysis (EFA) in order to derive an initial examination of the factorial structure and dimensionality of the mall image attributes. The results of EFA were studied through confirmatory and the unidimensionality of the partial constructs. The exploratory factor analysis led to the discovery of five factors that together construed 67.9 per cent of the total variation of the initial variables.

Table 2: Exploratory factor analysis results for mall image attributes

\begin{tabular}{|c|c|c|c|}
\hline Factors (varimax method) & Items loading in each factor & Loadings & $\begin{array}{l}\text { Cronbach's } \\
\text { alpha } \\
\text { coefficients }\end{array}$ \\
\hline \multirow{7}{*}{ Factor 1: Merchandising } & -A great product variety is available & 0.917 & \multirow{7}{*}{0.913} \\
\hline & -The product quality in this mall is very & 0.886 & \\
\hline & good & 0.769 & \\
\hline & -I always find this mall with full shelves & 0.701 & \\
\hline & -I can say I find the products that I need & 0.699 & \\
\hline & -I like the colours & 0.641 & \\
\hline & -I have no problem with the labels & & \\
\hline \multirow[t]{4}{*}{ Factor 2: Atmosphere } & -Appropriate temperature & 0.909 & \multirow{4}{*}{0.901} \\
\hline & -Very good air-cleaning system & 0.865 & \\
\hline & -Cleanliness & 0.799 & \\
\hline & -Pleasant smell & 0.783 & \\
\hline \multirow{3}{*}{ Factor 3: Accessibility } & -Transport to shopping mall & 0.901 & \multirow{3}{*}{0.899} \\
\hline & -Availability of parking space & 0.854 & \\
\hline & -Convenience of navigation & 0.854 & \\
\hline \multirow[t]{3}{*}{ Factor 4: Entertainment } & -The prices are low comparative the major & 0.830 & \multirow{3}{*}{0.701} \\
\hline & competitors & 0.589 & \\
\hline & $\begin{array}{l}\text {-The price quality relation is very good } \\
\text {-The prices are very good }\end{array}$ & 0.869 & \\
\hline \multirow{3}{*}{$\begin{array}{l}\text { Factor } 5 \\
\text { convenience }\end{array}$} & -The corridors are spacious & 0.827 & \multirow{3}{*}{0.647} \\
\hline & $\begin{array}{l}\text {-Trolleys and baskets help me in my } \\
\text { shopping errands }\end{array}$ & 0.669 & \\
\hline & -Clear shelving and neat signage & 0.663 & \\
\hline
\end{tabular}

Based on the preliminary data analysis as well as the EFA results reported in Table 2, respondents indicated that customers behaved in similar ways in choosing a shopping mall. Five most imperative image attributes were derived from various variables that were under study:

- Merchandising (the products, quality variety and availability),

- Atmosphere (pleasant interior design of the shopping mall),

- Accessibility (distance to the shopping mall),

- Entertainment (the variety of recreation and catering service)

- In-mall convenience (ease of navigation inside the shopping mall) 
Table 3: ANOVA - Customer satisfaction and mall patronage

\begin{tabular}{lllllll}
\hline \multirow{2}{*}{ ASGr } & $\begin{array}{l}\text { Sum } \\
\text { Squares }\end{array}$ & of & df & Mean Square & F & Sig. \\
& Between Groups & 19.785 & 9 & 2.198 & 6.981 & $* 0.000$ \\
& Within Groups & 115.905 & 263 & 0.441 & & \\
& Total & 135.690 & 272 & & & $*$ \\
& Between Groups & 13.072 & 9 & 1.452 & 3.139 & $* 0.043$ \\
\multirow{2}{*}{ FaLC } & Within Groups & 240.729 & 263 & 0.915 & & \\
& Total & 253.801 & 272 & & & \multirow{2}{*}{0.059} \\
& Between Groups & 11.322 & 9 & 1.258 & 2.389 & \\
& Within Groups & 238.129 & 263 & 0.905 & & $* 0.014$ \\
& Total & 249.451 & 272 & & & \\
& Between Groups & 19.993 & 9 & 2.221 & 21.371 & \\
& Within Groups & 246.456 & 263 & 0.937 & & \\
& Total & 266.449 & 272 & & & \\
\hline
\end{tabular}

Note $^{*}=$ statistically significant at $95 \%$ level of confidence; ASGr=age-subgroups; EduL=educational level; FaLC=family life cycle; ShoFr=shopping frequency

Results further showed that an absolute majority of respondents indicated merchandising $(\alpha=0.913)$ as the most significant image attribute in choosing the shopping mall. The first preference to this attribute was given by 74 percent of the surveyed customers. The investigation of their assessments revealed that in choosing a shopping mall the most important issue was the availability of preferred brands, followed by the atmosphere $(\alpha=0.901)$. The atmosphere focused on the significance of designs and pleasant interior decors of the shopping mall. The third position was given to accessibility of the shopping mall $(\alpha=0.899)$ which was the location of the shopping mall, road arteries into the mall, transportation systems and the parking space. Although entertainment $(\alpha=0.701)$ was rated fourth, it was reported as having the capacity to draw new visitors to the mall through a variety of catering services and recreational activities for both children and adults. The fifth factor, the in-mall convenience $(\alpha=0.647)$, referring to the convenience of navigation within the shopping mall. Customers prefer shopping malls with ease movements from one store to another, comfortable escalators and lifts from one floor to another. Table 3 shows the results of the ANOVA tests.

In examining the importance among demographic variables in influencing customer satisfaction and patronage, various tests were shown. Precisely, a $t$-test result showed that both male and female did not differ in their satisfaction level $(t=0.378, p=0.706)$ and their level of shopping mall patronage $(t=0.401, p=0.679)$. Henceforth, gender appeared a non-significant determinant of both customer satisfaction and patronage. However, a noteworthy difference existed between age-subgroups as observed from the ANOVA test results $(\mathrm{F}=6.891, p=0.000)$. Likewise, results for educational level $(\mathrm{F}=3.139, p=0.043)$, family life cycle $(\mathrm{F}=2.389$, $p=0.059)$, and shopping frequency $(\mathrm{F}=21.039, p=0.014)$ exhibited significant differences in each of the demographic variable subsections and customer satisfaction levels at $5 \%$ level of significance. According to Singh and Sahay (2012), this is indicative of differences in behavioural tendencies among shoppers based on their age-groups, levels of education and their marital status. Singh and Sahay (2012) further noted ambience, convenience to shopper and dynamic marketing focus as some of the most vital factors that drive customers to visit shopping malls.

\section{Conclusion}

The study revealed interesting findings regarding the constructs of mall image attributes and the interrelationship between its diverse dimensions. Five major features were underlined for the South African market: merchandising, atmosphere, accessibility, entertainment, and in-mall convenience. The findings are consistent with Arslan, Sezer and Isigicok's (2010) Turkish consumers' study which revealed comfort, retail environment, conditions, socialising in a secure environment, leisure and accessibility as important components of mall attributes. Interestingly, the results of this study advocate that visiting a shopping mall is more task-oriented and is a coherent behaviour stirred by extrinsic sensible motivations. Furthermore, results demonstrated that shopping mall image-attributes and customer satisfaction relationships are robust in a South African township context, influencing patronage. Four of these five features emerged as 
momentous determinants of customer satisfaction in line with Berman and Evans (2007). The study findings are in accordance with the human motivation and hedonic shopping consumption theory of Hirschman (1981). A study by Nicholls, Li, Mandokovic, Roslow and Kranendonk (2000) showed that customers mostly focus on the availability of entertainment and recreation within the shopping mall (Wong, Lu \& Yuan, 2001). The findings in this study also provide some differences with the Western economies who consider location, anchor tenant image and physical facilities as the most significant determinants of a shopping mall success (González-Hernández \& Orozco-Gómez, 2012). Research findings in China demonstrate that to customers, the most substantial attribute is eminence and diversity of stores and services, followed by location, popularity and facilities (Singh \& Sahay, 2012). The following recommendations can be useful for both mall developers and business from a marketing and strategic perspective.

Recommendations: Several theoretical implications flow from this research, suggesting a number of issues not only important to developers and managers of shopping malls in South Africa, but also merit further research. The knowledge of shopping mall image-attributes and proper combination of image-attributes is most significant for different market segments. This enables the application of numerous means of marketing strategies through different channels to help improve customer satisfaction and safeguard sufficient customer flows (patronage). Shopping mall developers can utilise these results in designing the shopping malls that appeal to visitors and hence increase the levels of both customer satisfaction and patronage.

Limitations: Firstly, this study was limited to mall image-attributes and customer satisfaction as a manifestation of consumer preference influencing patronage. Forthcoming research must put emphasis on other attitudinal and behavioural outcomes of customer satisfaction such as word-of-mouth and information search behaviour to examine whether loyalty also has any effect on these consequences. Secondly, this study focused on the mall image-attributes at one moment in time. However, mall image changes over time, both as a result of experiences with the shopping mall and the market socio-economic situation in general. It would be more informing to study the same shopping malls at different moments in time (longitudinal approach). A possible avenue for future research is the investigation of the relationship between the same variables for the various retailers within the shopping malls. Even though there is some evidence that shopping mall imageattributes is positively related customer satisfaction and patronage, it has remained blurred what the exact relationship between customer satisfaction and patronage of the various merchandisers in the malls is.

\section{References}

Anderson, E. \& Sullivan, M. (1993). The antecedents and consequences of customer satisfaction for firms. Marketing Science, 12, 125-43.

Anselmsson, J. (2006). Sources of customer satisfaction with shopping malls: a comparative study of different customer segments. International Review of Retail Distribution and Consumer Research, 16(1), 11538.

Arons, L. (1961). Does TV viewing influence mall image and shopping frequency? Journal of Retailing, 37(3), 1-13.

Arslan, T. V., Sezer, S. F. \& Isigicok, E. (2010). Magnetism of shopping malls on young Turkish consumers. Young consumers, 11(3), 178 - 188.

Babin, B. J. \& Darden. W. R. (1996). Good and bad shopping vibes: spending and patronage satisfaction. Journal of Business Research, 35(3), 201-6.

Berman, B. \& Evans, J. (2007). Retail Management: A Strategic Approach. 10th ed. Pearson, Prentice-Hall. Englewood Cliffs, NJ.

Bigne, E., Sanchez, I. \& Sanchez, J. (2001). Tourism image, evaluation variables and after purchase behavior: inter-relationship. Tourism Management, 22, 607-16.

Bloemer, J. \& Odekerke-Schroder, G. (2002). Mall satisfaction and mall loyalty explained by customer-and mall-related factors. Journal of Consumer Satisfaction, Dissatisfaction and Complaining Behavior, 15, 68-80.

Bloemer, J. \& De Rutyer, K. (1998). On the relationship between mall image, mall satisfaction, and mall loyalty. European Journal of Marketing, 32(5), 499-514.

Brunner, J. A. \& Mason, J. (1968). The influence of driving time upon shopping centre preference. Journal of Marketing, 32 (2), 57-61. 
Bucklin, L. P. (1967). The concept of mass in intra-urban shopping. Journal of Marketing, 31(4), 37-42.

Chang, C. H. \& Tu, C. Y. (2005). Exploring mall image, customer satisfaction and customer loyalty relationship: evidence form Taiwanese hypermarket industry. The journal of American Academy of Business, 7(2), 197-202.

Crawley, A. E. (1993).The two-dimensional impact of color on shopping. Marketing Letters, 4, 59-69.

Creswell, J. W. (2003). Research Design: Quantitative, Qualitative and Mixed Approaches. London: Sage Publications.

Darian, J. C., TucciI, L. A. \& Wiman, A. R. (2001). Perceived salesperson service attributes and retail patronage intentions. International Journal of Retail \& Distribution Management, 29(5), 205-13.

Dennis, C., Marsland, D. \& Cockett, T. (2002). Central Place Practice: Shopping Centre Attractiveness Measures, Hinterland Boundaries and the UK Retail Hierarchy. Journal of Retailing and Consumer Services, 9(4), 185-99.

Doyle, P. \& Fenwick, I. (1975). How mall image affects shopping habits in grocery chains. Journal of Retailing, $50(4), 39-52$.

Finn, A. \& Louviere, J. (1996). Shopping centre image, consideration and choice: anchor mall distribution. Journal of Business Research, 35(3), 241-51.

González-Hernández, E. M. \& Orozco-Gómez, M. (2012). A segmentation study of Mexican consumers based on shopping centre attractiveness. International Journal of Retail \& Distribution Management, 40(10), 759-777.

Grewal, D., Baker, J., Levy, M. \& Voss, G. B. (2003). The effects of wait expectations and store atmosphere evaluations on patronage intentions in service-intensive retail stores. Journal of Retailing, 79, 259-68.

Gudonaviciene1, R. \& Alijosiene, S. (2013). Influence of shopping centre image attributes on customer choices. Economics and Management, 18(3), 545-552.

Hartman, K. B. \& Spiro, R. L. (2005). Recapturing mall image in customer-based mall equity: a construct conceptualization. Journal of Business Research, 58(8), 1112-1120.

Heijden, H. \& Verhagen, T. (2004). Online mall image: conceptual foundations and empirical measurement. Information \& Management, 41(5), 609-17.

Hilderbrandt, L. (1988). Mall image and the prediction of performance in retailing. Journal of Business Research, 17(1), 91-100.

Hirschman, E. (1981). Retail Research and Theory, in Enis, B. M. \& Roering, K. J. (Eds), Review of Marketing, American Marketing Association. Chicago: IL.

Huff, D. L. (1964). Defining and Estimating a Trading Area. Journal of Marketing, 28, 34-38.

Hunter, G. L. (2006). The Role of Anticipated Emotion, Desire and Intention in the Relationship between Image and Shopping Centre Visits. International Journal of Retail and Distribution Management, 34, 709-721.

Kim, J. O. \& Jin, B. (2001). Korean consumers' patronage of discount malls: domestic vs. multinational discount mall shoppers profiles. Journal of Consumer Marketing, 18(3), 236-55.

Koo, D. M. (2003). Inter-relationships among mall images, mall satisfaction, and mall loyalty among Korea discount retail patrons. Asia Pacific Journal of Marketing and Logistics, 15(4), 42-71.

Loudon, D. L. \& Bitta, A. J. D. (1993). Consumer Behavior: Concepts and Applications, $4^{\text {th }}$ Ed. New York: McGraw-Hill.

Malhotra, N. K. (2004). Marketing Research: An Applied Orientation. $3^{\text {rd }}$ ed. Englewood Cliffs: Prentice-Hall.

Malhotra, N. K. (2010). Marketing Research: An Applied Orientation. $6^{\text {th }}$ ed. Englewood Cliffs: Prentice-Hall.

Martineau, P. (1958). The personality of the retail mall. Harvard Business Review, (36), 47-55.

Martins, L. M., Loubser, M. \& Van Wyk, H. D. J. (1996). Marketing Research: A South African Approach. Pretoria: UNISA Press.

Mitchell V. W. \& Kiral, R. H. (1998). Primary and Secondary Store-Loyal Customer Perceptions of Grocery Retailers. British Food Journal, 100(7), 312-319.

Nevin, J. R. \& Houston, M. (1980). Images as a component of attractiveness to intra-urban shopping areas. Journal of Retailing, 17(4), 46-9.

Nicholls, J. A. F., Li, F., Mandokovic, T., Roslow, S. \& Kranendonk, C. J. (2000). US-Chilean mirrors: shoppers in two countries. Journal of Consumer Marketing, 17(2), 106-119.

Oxenfeld, A. (1974). Developing a favourable price-quality image. Journal of Retailing, 50(4), 8-14.

Singh, H. \& Sahay, V. (2012). Determinants of shopping experience: Exploring the mall shoppers of national capital region of India. International Journal of Retail \& Distribution Management, 40(3), 235-248. 
Sit, J., Merrilees, B. \& Birch, D. (2003). Entertainment-seeking shopping centre patrons: the missing segments. International Journal of Retail \& Distribution Management, 31(2), 80-94.

Stanley, T. J. \& Sewall, M. A. (1976). Image inputs to a probabilistic model: predicting retail potential. Journal of Marketing, 40, 48-53.

Thang, D. C. L. \& Tan, B. L. B. (2003). Linking consumer perception to preference of retail stores: an empirical assessment of the multi-attributes of store image. Journal of retailing and consumer services, 10,193200.

Tustin, D. H., Ligthelm, A. A., Martins, J. H. \& Van Wyk, H. D. J. (2005). Marketing research in practice. Pretoria: UNISA.

Woodside, A. G. \& Trappey, R. J. (1992). Finding out why customers shop your store and buy your brand: Automatic cognitive processing models of primary choice. Journal of Advertising Research, 32, 59-78.

Wong, K. M., Lu, Y. \& Yuan, L. L. (2001). SCATTR: an instrument for measuring shopping centre attractiveness. International Journal of Retail \& Distribution Management, 29(2), 76-86.

Wyckham, R. G. (1967). Aggregate department store image: social and experimental factors. Proceedings of the American Marketing Association Conference. Chicago: American Marketing Association.

Zhuang, G., Tsang, A. S. L., Zhou, N., Li, F. \& Nicholls, J. A. F. (2006). Impacts of situational factors on buying decisions in shopping malls. European Journal of Marketing, 40(1), 17-43.

Zimmer, M. R. \& Golden, L. L. (1988). Impressions of retail stores: A content analysis of consumer images. Journal of Retailing, 64, 265-91. 